\title{
Analyze The Factors Of Clean Energy Consumption In China: Do Environmental Stringency Policies, Environmental Law, And Human Capital Matter?
}

\section{Feng Wu}

Zhongnan University of Economics and Law

\section{Yanting Ji}

Sichuan International Studies University

\section{Adnan Maqbool}

Khwaja Fareed University of Engineering \& Information Technology

Zubaria Andlib ( $\nabla$ zandlib@yahoo.com)

FUUAST: Federal Urdu University of Arts Sciences and Technology

\section{Research Article}

Keywords: Environmental stringency policies, Environmental law, Education, Clean energy consumption, China.

Posted Date: March 2nd, 2022

DOI: https://doi.org/10.21203/rs.3.rs-1310067/v1

License: (9) This work is licensed under a Creative Commons Attribution 4.0 International License. Read Full License 
Analyze the factors of clean energy consumption in China: do environmental stringency policies, environmental law, and human capital matter?

Feng Wu

School of international business and management, Sichuan International Studies University, Chongqing, China.

Criminal Justice School, Zhongnan University of Economics and Law, Wuhan, China.

Department of Management Sciences, Khwaja Fareed University of Engineering and Information Technology, R. Y. Khan, Pakistan.

\section{Zubaria Andlib**}

**Corresponding author

Department of Economics, Federal Urdu University, Islamabad, Pakistan. zandlib@yahoo.com

\section{Abstract}

Environmental stringency policies and education are becoming fundamental policy instruments for clean energy consumption but no study has been done to explore their impacts on clean energy consumption especially in China. The study addresses this gap by assessing the asymmetries of these two instruments in clean energy consumption for the period 1993 to 2019 by applying the NARDL approach. Further, we also explore the role of environmental law and education in clean energy consumption. Electric power consumption is used to measure the clean energy consumption effect, however, nuclear and renewables consumption is also used for checking the robustness of the findings. We found that positive change in environmental policy stringency leads to an upsurge in electric power consumption and nuclear and renewable energy consumption, while, negative change in environmental policy stringency has also a positive impact on electric power consumption and nuclear and renewable energy consumption in the long-run. Education and environmental law have a positive impact on electric power consumption; however, it does not affect nuclear and renewable energy consumption in the long-run. The findings suggest that environmental China. 


\section{Introduction}

Economic growth is positively correlated with energy consumption, as the economy grows it requires more energy to meet the demand of its fast pacing growth process (Apergis \& Ozturk, 2015 and Bildirici \& Gökmenoğlu, 2017). The major downside of consuming more energy appears in the form of environmental degradation because in most of the emerging economies the overall energy mix contains a high proportion of non-renewable energy sources that leads to more emissions of greenhouse gasses (Pata, 2018). Over the years, the developed economies have significantly reduced their reliance on dirty energy sources such as coal, oil, and gas (Balcilar et al., 2018 and Usman et al., 2020) and focused more on cleaner or renewable energy sources such as solar, wind, hydel, and nuclear. Environmental degradation was not the only concern behind this shifting rather they want to reduce their dependency on the countries which are the major producers of fossil fuels. Accordingly, the European Union (EU) has introduced various policies and strategies that will increase the share of clean energy to $27 \%$, in total energy, by the end of the year 2030 (EUROSTAT, 2017).

Over the last few decades, China's remarkable economic development was supplemented by immense surges in energy demand. Certainly, since 2009 China has become the world's leader in energy consumption by surpassing the United States. In 2019, China's energy consumption was 4.87 billion tons of standard coal equivalent (SCE). The share of fossil fuels in total energy consumption was $86 \%$ in the year 2018. Against this background, recognizing the fundamental factors behind China's massive energy demand is vital for estimating its energy requirement and energy safety in the forthcoming (Odgaard and Delman, 2014). Additionally, this information is important to forecasting price instabilities fetched by China's dynamic involvement in the international energy market (Ratti and Vespignani, 2013). Lastly, due to the rising contribution of China in the total emissions of global greenhouse gasses i.e. almost one-third of the total world's emissions, comprehension of its energy-demand arrangement offers essential information to fight global climate variation (Li et al., 2016).

A large number of studies are available that have tried to find the impact of energy consumption on China's economic progress (Yuan et al., 2008 and Bloch et al., 2015). Freshly, some of the researchers have successfully observed the role of mechanization, urbanization, and economic revolution in rising energy demand (Zhao et al., 2020). Endogenous growth theory considers human capital as an important factor in pacing the growth of the economy and, growth led by human capital will be more sustainable as it is complemented by technological innovations (Aghion and Howitt, 1998; Lucas, 1988; Romer, 1990), hence, exert less burden on the environment due to significant decrease in the consumption of dirty energy.

Theoretically, whilst human capital can reduce energy consumption due to innovations and the development of energy-efficient products, it increases energy consumption due to the growth effect in the economy. Empirically, one of the earliest studies by Pachauri and Jiang (2008) in the Chinese context observed that more educated domestic consumers select energy-efficient smart appliances. Likewise, Démurger and Fournier (2011) reported that as the education level in rural families goes up in the northern part of China they increase the consumption of commercially available sources of fuel like coal in comparison to the less-efficient sources such as firewood. A similar type of findings was also reported by Broadstock et al. (2016) and confirmed that more 
more on energy efficiency. Contrariwise, Broadstock et al. (2016) pointed out that electricity consumption goes up together with the increased income among the highly educated families in Beijing, Shanghai and Guangdong and their findings were complemented by Khanna et al. (2016), though they used quite a bigger dataset. According to Me et al. (2009), in the production function, the swap between human capital and energy sources is more viable at the national level rather than regional. Consequently, Salim et al. (2017) used the aggregate data for the Chinese economy and confirmed that, in the trans-log production process, substitution can take place successfully between the human capital and energy.

A higher level of education can also make the citizens more law-abiding and responsible, hence, under such a situation the environmental law can serve as an important tool in inducing the people towards the use of clean energy consumption. In this context, China's $11^{\text {th }}$ five-year plan (2006-10) proved to be a turning point that has transformed the mindset of bureaucrats who started to emphasize more on the policies of environmental protection and took stern action against the violators by forcefully imposing the shutdowns on the obsolete production facilities that were detrimental to the environment (Wang et al., 2013). The legal agenda of clean energy in China has significantly supported the accomplishments previously made in this regard; though, it is still inadequate to assimilate clean energy into China's national energy arrangement (Liu, 2019). Environmental stringency policy is a key factor of renewable energy consumption (Brunel \& Levinson, 2016 and Galeotti et al., 2020). However, empirically not many shreds of evidence are available that could tell us whether the environmental stringency policies and environmental laws help build the economy based on clean energy.

In this study, we are mainly concerned with two pertinent questions: How the education impacts the clean energy consumption of China at the national level? Can the environmental laws push society towards the use of clean energy? How do environmental stringency policies improve clean energy consumption? Clean energy can be defined as energy sources that are mainly dependent on solar, wind, biofuels, hydel, nuclear, and are environmentally friendly because they release less $\mathrm{CO}_{2}$. To our knowledge, this is the first-ever empirical study, with special reference to China, that has tried to examine the role of education and environmental laws on the use of clean energy consumption in China. In addition, we have applied the asymmetry assumption between environmental stringency policies and clean energy consumption which is more reliable because it provides an opportunity to break our main variables into their positive and negative changes.

\section{Model and methods}

To explore the influence of environmental policy stringency, environmental law, and education on CO2 emissions, we estimate the following long-run model:

$$
\mathrm{CEC}_{\mathrm{t}}=\alpha_{0}+\alpha_{1} \mathrm{EPS}_{\mathrm{t}}+\alpha_{2} \text { Education }_{\mathrm{t}}+\alpha_{3} \mathrm{ER}_{\mathrm{t}}+\alpha_{4} \mathrm{ET}_{\mathrm{t}}+\mu_{\mathrm{t}}------(1)
$$

Where CEC is clean energy consumption, EPS is environmental policy stringency, education is educational attainment, ER is environmental regulation, and ET is environmental technology in the model. Equation (1) provides 
the long-run estimates only; however, we are concerned with both short-run and long-run estimates. To that end, we need to reconsider the above equation in the error correction format as displayed below:
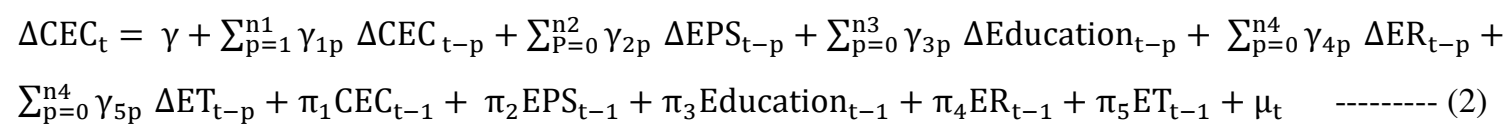

Specification (2) has occupied the form of the linear ARDL of Pesaran et al. (2001). Once we estimate equations (2), we get both long-run with short-run estimates simultaneously. The estimates connected to the first-difference indicators $(\Delta)$ represent the short-run estimates; whereas, the estimates connected to $\pi_{2}-\pi_{5}$ normalized on $\pi_{1}$ are long run. Moreover, this method is efficient in a small sample size. Another advantage is that pre-unit root testing is not a prerequisite for ARDL. This method provides robust estimates even as the variables are incorporated by distinct orders such as $\mathrm{I}(0)$ otherwise $\mathrm{I}(1)$. But we cannot include any variable, which is $\mathrm{I}(2)$. Shin et al. (2014) transform the above approach so that we can also examine the possibility of asymmetries, which contain positive changes in environmental policy stringency as well as negative changes. The mathematical form of the partial sum procedure is presented below:

4

5

$$
\begin{aligned}
& \mathrm{EPS}_{\mathrm{t}}^{+}=\sum_{\mathrm{n}=1}^{\mathrm{t}} \Delta \mathrm{EPS}^{+}{ }_{\mathrm{t}}=\sum_{\mathrm{n}=1}^{\mathrm{t}} \max \left(\Delta \mathrm{EPS}^{+}{ }_{\mathrm{t}}, 0\right) \\
& \mathrm{EPS}_{\mathrm{t}}{ }_{\mathrm{t}}=\sum_{\mathrm{n}=1}^{\mathrm{t}} \Delta \mathrm{EPS}^{-}{ }_{\mathrm{t}}=\sum_{\mathrm{n}=1}^{\mathrm{t}} \min \left(\Delta \mathrm{EPS}^{-}{ }_{\mathrm{t}}, 0\right)
\end{aligned}
$$

In equation (3a), EPS ${ }^{+}$represents the positive changes in the series, whereas equation (3b) EPS $^{-}$represents the negative changes in the selected series. Next, we incorporate these partial sum variables in place of the original variables as shown below:

$$
\begin{aligned}
\Delta \mathrm{CEC}_{\mathrm{t}}=\alpha_{0}+ & \sum_{\mathrm{k}=1}^{\mathrm{n}} \beta_{1 \mathrm{k}} \Delta \mathrm{CEC}_{\mathrm{t}-\mathrm{k}}+\sum_{\mathrm{k}=0}^{\mathrm{n}} \beta_{2 \mathrm{k}} \Delta \mathrm{EPS}^{+}{ }_{\mathrm{t}-\mathrm{k}}+\sum_{\mathrm{k}=0}^{\mathrm{n}} \delta_{3 \mathrm{k}} \Delta \mathrm{EPS}^{-}{ }_{\mathrm{t}-\mathrm{k}}+\sum_{\mathrm{k}=0}^{\mathrm{n}} \beta_{4 \mathrm{k}} \text { Education }_{\mathrm{t}-\mathrm{k}}+\sum_{\mathrm{k}=0}^{\mathrm{n}} \delta_{5 \mathrm{k}} \mathrm{ER}_{\mathrm{t}-\mathrm{k}} \\
& +\sum_{\mathrm{k}=0}^{\mathrm{n}} \delta_{6 \mathrm{k}} \mathrm{ET}_{\mathrm{t}-\mathrm{k}}+\omega_{1} \mathrm{CEC}_{\mathrm{t}-1}+\omega_{2} \mathrm{EPS}^{+}{ }_{\mathrm{t}-1}+\omega_{3} \mathrm{EPS}^{-} \mathrm{t}-1 \\
& +\omega_{6} \mathrm{ET}_{\mathrm{t}-1}+\mu_{\mathrm{t}} \text { Education }_{\mathrm{t}-1}+\omega_{5} \mathrm{ER}_{\mathrm{t}-1}
\end{aligned}
$$

After entering the partial sum variables in place of original variables, the new equation (4) is known as the NARDL of Shin et al. (2014), which is a new form of the ARDL model. This method is subject to the same cointegration test and critical values as Pesaran et al. (2001) proposed for the linear ARDL model. However, few asymmetric tests are to be applied to confirm the presence of asymmetry in the impacts of positive and negative components of EPS. First, we see if the size of the estimate attached to $\triangle \mathrm{EPS}^{+}$at a particular lag is different from the size of the estimate 
attached to $\triangle \mathrm{EPS}^{-}$or not, and if they are different this is a sign of short asymmetry. Then, to confirm the short-run asymmetries, we nullified the null hypothesis of Wald-SR, i.e., $\sum \beta_{2 \mathrm{k}}=\sum \beta_{3 \mathrm{k}}$. Finally, the long asymmetries will confirm if we nullified the null hypothesis of Wald-LR i.e. $\frac{w_{2}}{-w_{1}}=\frac{w_{3}}{-w_{1}}$.

\section{Data}

The study uses annual data for China covering the time period from 1993 to 2019 . The study has to take this time period for empirical investigation as the data for environmental regulation and environmental technology is not available before 1993. Table 1 delivers information regarding definitions of variables and sources of data. Data on electric power consumption is sourced from the World bank, it is measured in electric power consumption as kWh per capita. Nuclear and renewables consumption is measured in quad Btu and retrieved from EIA. Data on environmental policy stringency is occupied from the database of OECD. This index value ranges from 0 to 6 where 0 stands for no stringency and 6 depicts the highest degree of stringency. The variable on a year of schooling is measured as an average year of schooling and data is obtained from Barro and Lee. Data on environmental regulation and environmental technology is sourced from OECD. Environmental regulation is measured by environmental-taxes as a percent of total tax revenue and environmental technology is measured by environmentrelated technologies.

Table 1: Definitions and data sources

\begin{tabular}{|c|c|c|c|}
\hline Variables & $\begin{array}{l}\text { Abbreviation } \\
\text { s }\end{array}$ & Definitions & $\begin{array}{l}\text { Data } \\
\text { source } \\
\text { S }\end{array}$ \\
\hline $\begin{array}{l}\text { Electric power } \\
\text { consumption }\end{array}$ & EPC & Electric power consumption ( $\mathrm{kWh}$ per capita) & $\begin{array}{l}\text { World } \\
\text { bank }\end{array}$ \\
\hline $\begin{array}{l}\text { Nuclear and renewables } \\
\text { consumption }\end{array}$ & NRC & Nuclear, renewables, and other (quad Btu) & EIA \\
\hline $\begin{array}{l}\text { Environmental policy } \\
\text { stringency }\end{array}$ & EPS & $\begin{array}{l}\text { Environmental policy stringency index ranges from } 0 \text { (not stringent) to } \\
6 \text { (highest degree of stringency) }\end{array}$ & OECD \\
\hline Year of schooling & Education & Average year of schooling & $\begin{array}{l}\text { Barro } \\
\text { and } \\
\text { Lee }\end{array}$ \\
\hline $\begin{array}{l}\text { Environmental } \\
\text { regulation }\end{array}$ & ER & Environmentally related taxes, $\%$ total tax revenue & OECD \\
\hline $\begin{array}{l}\text { Environmental } \\
\text { technology }\end{array}$ & ET & Environment-related technologies & OECD \\
\hline
\end{tabular}

\section{Empirical results and discussion}

Before estimating the long and short-run results, Table 2 reported the unit root test results without and with break. The results of these unit root tests confirm that most of our variables are stationary at the first difference; however, the variable of EPS is stationary at a level in Zivot-Andrews test, while remaining all variables are stationary at the level in ADF test. After confirming the stationarity of our variables we can apply the NARDL method. Table 3, demonstrated the results of basic and robust models along with all diagnostic and cointegration tests. The results of cointegration tests i.e. F-test and $\mathrm{ECM}_{\mathrm{t}-1}$ confirm that the variables of EPC (NRC), EPS, Education, ER, and ET are cointegrated in both the models inferring that our long-run results are valid. 
Table 2: Unit root testing

\begin{tabular}{|c|c|c|c|c|c|c|c|c|}
\hline & \multicolumn{3}{|c|}{ Unit root without break } & \multicolumn{5}{|c|}{ Unit root with break } \\
\hline & $I(0)$ & $I(1)$ & Decision & $I(0)$ & Break date & I(1) & Break date & Decision \\
\hline EPC & -1.564 & $-3.741 * *$ & $I(1)$ & -3.212 & 2002 & $-9.821 * * *$ & 2015 & I(1) \\
\hline NRC & -1.256 & $-4.875^{* * *}$ & $\mathrm{I}(1)$ & -0.884 & 2016 & $-4.235^{*}$ & 2012 & I(1) \\
\hline EPS & -0.345 & $-3.875 * * *$ & $I(1)$ & -3.521 & 2010 & & & $I(0)$ \\
\hline Education & -0.123 & $-3.255^{* *}$ & $\mathrm{I}(1)$ & -2.974 & 2003 & $-4.354^{*}$ & 2017 & $I(1)$ \\
\hline ER & -1.635 & $-3.865^{* * *}$ & $\mathrm{I}(1)$ & -2.987 & 2015 & $-11.98 * * *$ & 2013 & $I(1)$ \\
\hline ET & -1.212 & $-2.645^{*}$ & $I(1)$ & -3.012 & 2003 & $-4.321 *$ & 2015 & $I(1)$ \\
\hline
\end{tabular}

Note: $* * * p<0.01 ; * * p<0.05 ;$ and $* \mathrm{p}<0.1$

In the basic model, the long-run asymmetric estimate of EPS_POS is significantly positive, whereas, the estimate of EPS_NEG is insignificant. Variables are measured in the log forms except for the EPS, hence, we can interpret that a 1 point rise in environmental policy stringency index can increase the consumption of electricity by $1740.422 \%$, however, the relaxation in environmental policy stringency does not have a significant effect on the EPC. 175 Despite the rise in EPS in china, people increase the consumption of EPC suggesting that it has an inelastic demand. 176 In the robust model, the estimated coefficient attached EPS_POS (6.453\%) is significantly positive, whereas, the estimate attached to EPS_NEG $(2.225 \%)$ is a significant negative. This result implies that a rise in environmental policy stringency will push the people in China towards the consumption of clean energy, whereas, as the environmental policy in China is relaxed they still increase the consumption of clean energy suggesting that the demand for this energy is inelastic ${ }^{1}$. China's $11^{\text {th }}$ five-year plan, over the period 2006-10, played a pivotal role in changing the mindset of bureaucracy, businessmen and common people about the contribution of fossil fuels to environmental degradation and they started to pay more attention towards alternative sources of energy from that point onwards (Wang, 2013). Our finding is also consistent with Herman \& Xiang (2019), who noted that environmental policy stringency improves clean energy consumption. Our results are not surprising because the strict environmental law can have ultimate pressure on the firms to reduce their $\mathrm{CO} 2$ emissions to a sustainable level otherwise they have to face legal procedures and can face heavy fines and penalties and in some instances even closure. As a result, the firms start shifting their production process from non-renewable energy sources to renewable ones and start using more innovative technology that is more energy-efficient to curb the $\mathrm{CO} 2$ emissions. It is now a well-known fact that a negative externality is attached to atmospheric pollution and the market forces alone don't have the strength to mitigate these negative effects (Raufel and Weldemeskel, 2020). In a free economy, governments don't interfere with market forces, however, the quality of the environment provided by the free economy is not up to the mark, and hence, the need for environmental policy stringency becomes much more vital to correct the environment. Many countries have successfully reduced the inflow of carbon emissions into the environment by imposing taxes and restricting the use of dirty energy and adopting policies that encourage the use of renewable or clean energy sources (Revesz and Stavins, 2007 and Ozcan \& Ozturk, 2019).

${ }^{1}$ The size of magnitude attached to EPS_POS and EPS_NEG in the EPC model is small, whereas, in the NRC model it is large implying that though both the energies are essential for Chinese economies but the demand for renewable energy is more inelastic. 

asymmetric impacts of EPS on the EPC and NRC in China which is also established by the significant Wald-LR 198 statistics provided in Table 3.

Table 3: NARDL estimates of clean energy consumption

\begin{tabular}{|c|c|c|c|c|c|c|c|c|}
\hline \multirow[b]{3}{*}{ Variable } & \multicolumn{4}{|l|}{ Basic model } & \multicolumn{4}{|c|}{ Robustness model } \\
\hline & \multicolumn{4}{|l|}{ EPC } & \multicolumn{4}{|l|}{ NRC } \\
\hline & Coefficient & S.E & t-Stat & Prob. & Coefficient & S.E & t-Stat & Prob. \\
\hline \multicolumn{9}{|l|}{ Short-run } \\
\hline D(EPS_POS) & 0.011 & 0.051 & 0.220 & 0.831 & $0.608^{*}$ & 0.365 & 1.665 & 0.100 \\
\hline D(EPS_POS(-1)) & -0.093 & 0.106 & 0.880 & 0.404 & & & & \\
\hline D(EPS_NEG) & -0.166 & 0.182 & 0.914 & 0.387 & $-2.184 * * *$ & 0.686 & 3.184 & 0.010 \\
\hline D(EPS_NEG(-1)) & & & & & $5.699 * * *$ & 1.033 & 5.516 & 0.000 \\
\hline D(EDUCATION) & $0.214 * * *$ & 0.061 & 3.490 & 0.008 & $-1.789 * * *$ & 0.565 & 3.166 & 0.010 \\
\hline D(EDUCATION(-1)) & $0.220 * * *$ & 0.046 & 4.740 & 0.002 & & & & \\
\hline$D(E R)$ & 0.024 & 0.024 & 0.993 & 0.350 & $0.737^{* * *}$ & 0.230 & 3.205 & 0.009 \\
\hline $\mathrm{D}(\mathrm{ER}(-1))$ & $-0.133 * * *$ & 0.012 & 10.82 & 0.000 & $-0.244 * *$ & 0.114 & 2.142 & 0.058 \\
\hline $\mathrm{D}(\mathrm{ET})$ & $0.155^{*}$ & 0.093 & 1.666 & 0.100 & $1.438 * *$ & 0.695 & 2.070 & 0.065 \\
\hline $\mathrm{D}(\mathrm{ET}(-1))$ & $0.356 * * *$ & 0.107 & 3.328 & 0.010 & & & & \\
\hline \multicolumn{9}{|l|}{ Long-run } \\
\hline EPS_POS & $0.422 * * *$ & 0.115 & 3.676 & 0.006 & $6.453 * * *$ & 1.929 & 3.345 & 0.007 \\
\hline EPS_NEG & -0.378 & 0.259 & 1.460 & 0.182 & $-2.225^{\star \star \star}$ & 0.784 & 2.836 & 0.017 \\
\hline EDUCATION & $0.105^{* * *}$ & 0.034 & 3.112 & 0.014 & 0.320 & 0.364 & 0.878 & 0.401 \\
\hline ER & $0.190 * *$ & 0.031 & 6.165 & 0.000 & 0.686 & 0.491 & 1.397 & 0.193 \\
\hline ET & $0.143^{* *}$ & 0.064 & 2.241 & 0.055 & 0.808 & 0.950 & 0.850 & 0.415 \\
\hline C & 6.583 & 0.574 & 11.46 & 0.000 & 4.101 & 8.512 & 0.482 & 0.640 \\
\hline \multicolumn{9}{|l|}{ Diagnostics } \\
\hline F-test & $6.535^{* * *}$ & & & & $8.391 * * *$ & & & \\
\hline $\mathrm{ECM}(-1)$ & -0.795 & 0.209 & 3.804 & 0.003 & $-0.653 * * *$ & 0.147 & -4.441 & 0.001 \\
\hline LM & 0.636 & & & & 1.510 & & & \\
\hline BGP & 0.719 & & & & 0.950 & & & \\
\hline RESET & 1.375 & & & & 1.323 & & & \\
\hline CUSUM & $\mathrm{S}$ & & & & $S$ & & & \\
\hline CUSUM-sq & $\mathrm{S}$ & & & & $S$ & & & \\
\hline W-LR & $14.06 * * *$ & & & & $6.689 * * *$ & & & \\
\hline W-SR & 0.290 & & & & $3.439 *$ & & & \\
\hline
\end{tabular}

Note: $* * * \mathrm{p}<0.01 ; * * \mathrm{p}<0.05 ;$ and $* \mathrm{p}<0.1$ estimated coefficient of education is significant and positive in the basic model, whereas, insignificant in the robust model - a $1 \%$ rise in the education level increase the electricity consumption in China by $0.105 \%$ (significant) in the 
knowledge is an important part of endogenous growth theory which helps the economy to grow (Benos and Zotou, 2014) and energy demand and growth are positively linked (Ozturk, 2010). However, education brings awareness and information among the people about the environment and they replace the non-renewable energy sources with renewable ones. Moreover, ethical and moral preaching's and environmental education can also change the behavior of people towards the environment and they start consuming more clean energy. However, the role of education in China needs to be enhanced to adopt NRC instead of traditional sources. Similarly, the long-run estimated coefficients of ET and ER are significant in the basic model, while, insignificant in the robustness model. From these finding, we deduce that a $1 \%$ rise in both ET and ER increase the use of EPC by $0.190 \%$ and $0.143 \%$. In the short run, the estimated coefficients of most of the variables provided the results as per our expectations and the results are provided in Table 3. However, the short-run nonlinear effects between EPS_POS and EPS_NEG is confirmed only in the robust model.

Under diagnostic, in table 3, we have carried the estimates of some investigative tests that further endorse the validity of our results. The first-order serial correlation is detected by Langrage Multiplier (LM) test, while, the heteroskedasticity in errors is detected by Breusch-Pagan (BP) test. The misspecification in the model is observed by Ramsey's RESET test and the parametric instability of the model is confirmed by CUSUM and CUSUM-sq. These tests confirm that our models are free from these problems. In figures $1 \& 2$, we draw the dynamic multiplier graphs on the basis of the NARDL model. Both the graph shows the combination of non-linear dynamic multipliers because of positive and negative changes in environmental policy stringency. To save space, Table 4 only discusses the outcomes of Granger causality between EPS and dependent variables. Findings show that one-way causality runs from EPC $\rightarrow$ EPS_POS and EPC $\rightarrow$ EPS_NEG in the base model. Similarly, in the robust model, uni-directional causality is running from $\mathrm{NRC} \rightarrow \mathrm{EPS} \_\mathrm{NEG}$.

29


244 Fig. 1 Asymmetric dynamic multipliers effects of EPS on electric power consumption

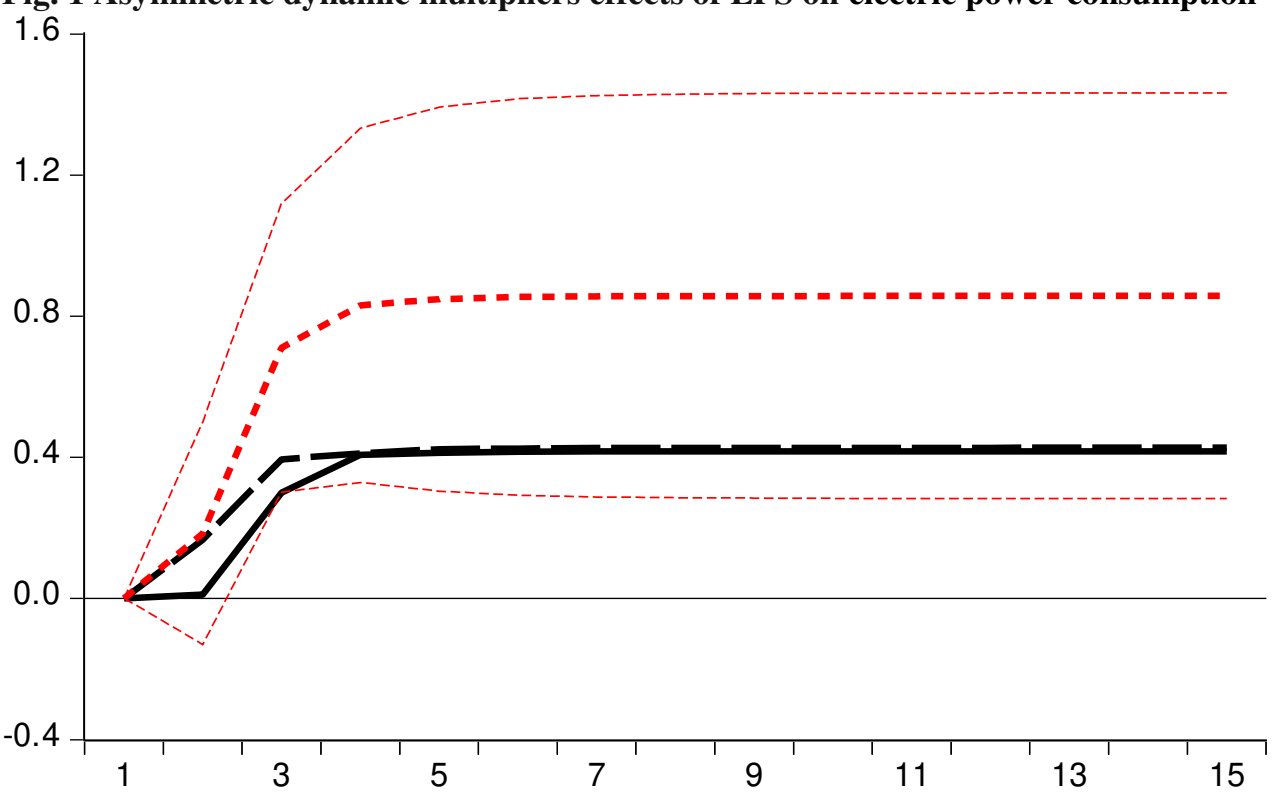

Multiplier for EPS(+)

- Multiplier for EPS(-)

--- Asymmetry Plot (with C.I.)

246

247

Fig. 2 Asymmetric dynamic multipliers effects of EPS on nuclear and renewable energy consumption

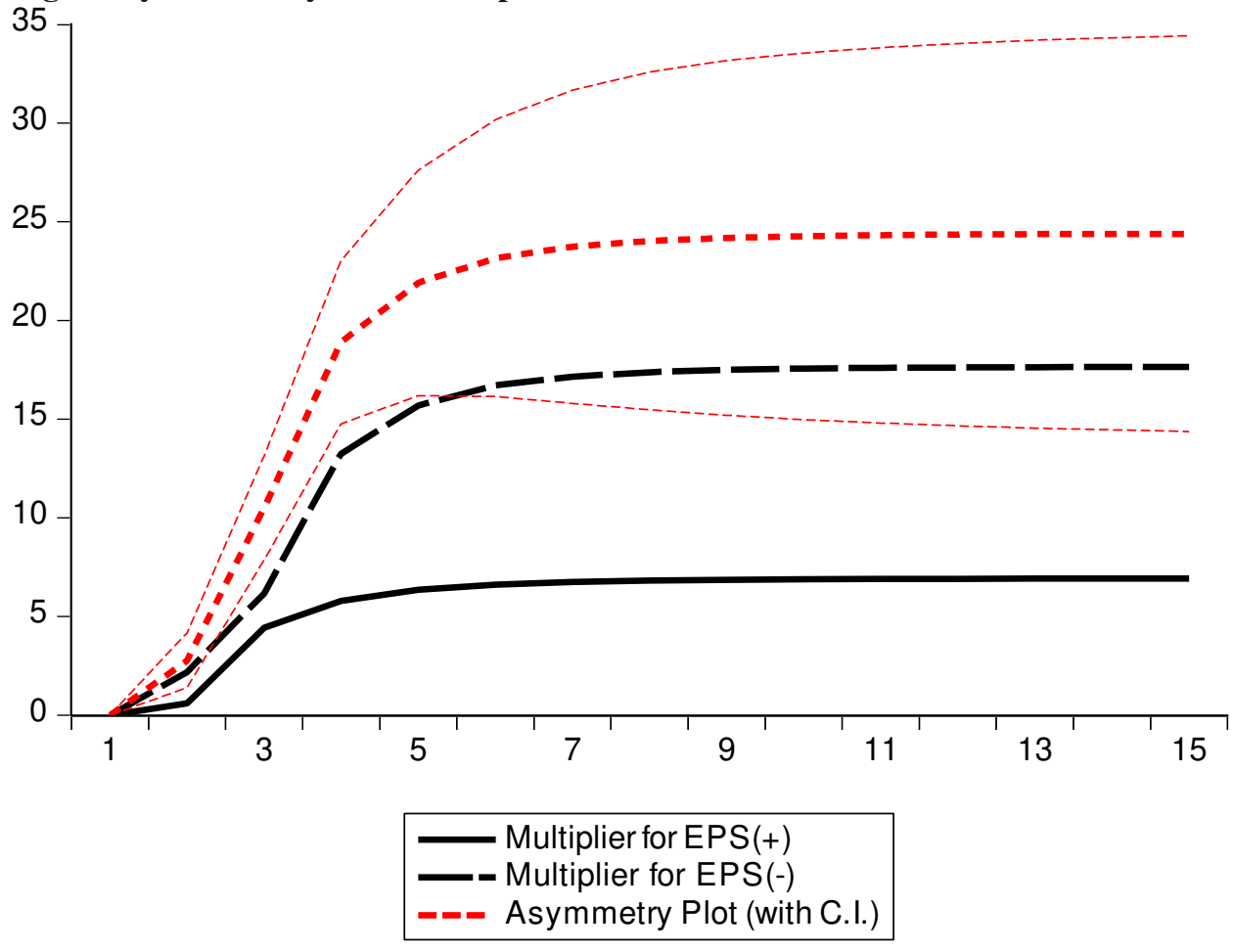


Table 4: Asymmetric causality

\begin{tabular}{|c|c|c|c|c|c|}
\hline Null Hypothesis: & F-Stat & Prob. & Null Hypothesis: & F-Stat & Prob. \\
\hline EPS_POS $\rightarrow$ EPE & 1.352 & 0.283 & EPS_POS $\rightarrow$ NRC & 2.074 & 0.153 \\
\hline EPE $\rightarrow$ EPS_POS & 2.702 & 0.093 & $N R C \rightarrow$ EPS_POS & 2.354 & 0.122 \\
\hline EPS_NEG $\rightarrow$ EPE & 0.061 & 0.941 & EPS_NEG $\rightarrow$ NRC & 1.300 & 0.296 \\
\hline EPE $\rightarrow$ EPS_NEG & 54.18 & 0.000 & NRC $\rightarrow$ EPS_NEG & 6.116 & 0.009 \\
\hline EDUCATION $\rightarrow$ EPE & 0.242 & 0.788 & EDUCATION $\rightarrow$ NRC & 9.450 & 0.001 \\
\hline EPE $\rightarrow$ EDUCATION & 1.488 & 0.250 & NRC $\rightarrow$ EDUCATION & 0.034 & 0.967 \\
\hline $\mathrm{ER} \rightarrow \mathrm{EPE}$ & 6.752 & 0.006 & $\mathrm{ER} \rightarrow \mathrm{NRC}$ & 8.906 & 0.002 \\
\hline $\mathrm{EPE} \rightarrow \mathrm{ER}$ & 2.034 & 0.157 & $\mathrm{NRC} \rightarrow \mathrm{ER}$ & 6.579 & 0.006 \\
\hline $\mathrm{ET} \rightarrow \mathrm{EPE}$ & 1.517 & 0.244 & $\mathrm{ET} \rightarrow \mathrm{NRC}$ & 8.003 & 0.003 \\
\hline $\mathrm{EPE} \rightarrow \mathrm{ET}$ & 3.588 & 0.047 & $\mathrm{NRC} \rightarrow \mathrm{ET}$ & 1.699 & 0.208 \\
\hline EPS_NEG $\rightarrow$ EPS_POS & 0.007 & 0.993 & EPS_NEG $\rightarrow$ EPS_POS & 0.007 & 0.993 \\
\hline EPS_POS $\rightarrow$ EPS_NEG & 4.622 & 0.023 & EPS_POS $\rightarrow$ EPS_NEG & 4.622 & 0.023 \\
\hline EDUCATION $\rightarrow$ EPS_POS & 4.992 & 0.018 & EDUCATION $\rightarrow$ EPS_POS & 4.992 & 0.018 \\
\hline EPS_POS $\rightarrow$ EDUCATION & 0.095 & 0.910 & EPS_POS $\rightarrow$ EDUCATION & 0.095 & 0.910 \\
\hline ER $\rightarrow$ EPS_POS & 3.503 & 0.051 & ER $\rightarrow$ EPS_POS & 3.503 & 0.051 \\
\hline EPS_POS $\rightarrow$ ER & 36.30 & 0.000 & EPS_POS $\rightarrow$ ER & 36.30 & 0.000 \\
\hline ET $\rightarrow$ EPS_POS & 3.025 & 0.072 & ET $\rightarrow$ EPS_POS & 3.025 & 0.072 \\
\hline EPS_POS $\rightarrow$ ET & 0.294 & 0.748 & EPS_POS $\rightarrow$ ET & 0.294 & 0.748 \\
\hline EDUCATION $\rightarrow$ EPS_NEG & 3.657 & 0.045 & EDUCATION $\rightarrow$ EPS_NEG & 3.657 & 0.045 \\
\hline EPS_NEG $\rightarrow$ EDUCATION & 0.740 & 0.490 & EPS_NEG $\rightarrow$ EDUCATION & 0.740 & 0.490 \\
\hline ER $\rightarrow$ EPS_NEG & 0.091 & 0.913 & ER $\rightarrow$ EPS_NEG & 0.091 & 0.913 \\
\hline EPS_NEG $\rightarrow$ ER & 0.818 & 0.456 & EPS_NEG $\rightarrow$ ER & 0.818 & 0.456 \\
\hline ET $\rightarrow$ EPS_NEG & 1.521 & 0.244 & ET $\rightarrow$ EPS_NEG & 1.521 & 0.244 \\
\hline EPS_NEG $\rightarrow$ ET & 3.859 & 0.039 & EPS_NEG $\rightarrow$ ET & 3.859 & 0.039 \\
\hline ER $\rightarrow$ EDUCATION & 0.851 & 0.442 & ER $\rightarrow$ EDUCATION & 0.851 & 0.442 \\
\hline EDUCATION $\rightarrow$ ER & 3.133 & 0.066 & EDUCATION $\rightarrow$ ER & 3.133 & 0.066 \\
\hline ET $\rightarrow$ EDUCATION & 3.955 & 0.036 & ET $\rightarrow$ EDUCATION & 3.955 & 0.036 \\
\hline EDUCATION $\rightarrow$ ET & 0.332 & 0.721 & EDUCATION $\rightarrow$ ET & 0.332 & 0.721 \\
\hline $\mathrm{ET} \rightarrow \mathrm{ER}$ & 1.794 & 0.192 & $\mathrm{ET} \rightarrow \mathrm{ER}$ & 1.794 & 0.192 \\
\hline $\mathrm{ER} \rightarrow \mathrm{ET}$ & 1.298 & 0.295 & $E R \rightarrow E T$ & 1.298 & 0.295 \\
\hline
\end{tabular}

253 Note: $* * * \mathrm{p}<0.01 ; * * \mathrm{p}<0.05 ;$ and $* \mathrm{p}<0.1$

\section{Conclusion and implications}

This paper attempts to investigate the impact of environmental policy stringency, environmental law,

258 education on clean energy consumption of China for the period 1993 to 2019. To our knowledge, this study is a

259 fresh attempt that is incorporating the role of environmental policy stringency, environmental law, and education in

260 the field of clean energy production. Primarily, clean energy production is measured through electric power

261 consumption, but in order to check the robustness of findings nuclear and renewable energy consumption is also 
used as a measure for clean energy consumption. The study adopted NARDL approach for determining the impact of environmental policy stringency on electric power consumption and nuclear renewables consumption. The findings reveal that positive shocks in environmental stringency policy result in increasing electric power consumption and nuclear and renewables consumption in the long-run revealing that environmental stringency policy leads to an upsurge in energy consumption. However, the negative shock in environmental stringency policy has a positive impact on electric power consumption and nuclear and renewables consumption in the long run.

The findings further infer that education, environmental regulation, and environmental technology leads to an upsurge in electric power consumption but the impact on nuclear and renewables consumption is not statistically significant. We found no association between negative and positive components of environmental policy stringency and electric power consumption in the short-run. However, positive shocks in environmental policy stringency exert a positive effect on nuclear and renewables consumption and negative shocks in environmental policy stringency also exert a positive impact on nuclear and renewables consumption in the short-run. We found a positive relationship between education and electric power consumption in the short-run implying that the higher level of education is improved consumption of electric power. In contrast, we found a negative relationship between education and nuclear and renewables consumption in the short-run revealing that a higher level of education leads to a reduction in nuclear and renewables consumption.

Based on the findings it is suggested that environmental stringency policies should be considered for clean energy consumption in China. The Chinese government should allocate more budgets for a clean environment and low-carbon economy. Institutional quality should be strengthened in China to offset the effects of the shadow economy. The environmental stringency policy, environmental laws, and clean energy consumption can be used as effective tools for enhancing the quality of the environment in China. Moreover, the Chinese government should adopt environmental laws as economic determinants to attain green growth for the expansion of sustainable economic growth. China should increase clean energy consumption by imposing strict environmental laws. Government should also increase environmental education for a sustainable lifestyle in China. Also, environmental pollution contents should be added to the academic syllabus at a basic level. The use of electronic and print media to create environmental awareness could also be useful. Further studies should also examine the nonlinear effects of

Ethical Approval: Not applicable

292 Consent to Participate: I am free to contact any of the people involved in the research to seek further clarification and information

294 Consent to Publish: Not applicable

295 Author's Contributions: This idea was given by Feng Wu. Feng Wu analyzed the data and wrote the complete paper. This article is done under the supervision of Yanting Ji. While Adnan Maqbool and Zubaria Andlib read and approved the final version.

298 Funding: Not applicable 
Competing Interests: The authors declare that they have no conflict of interest.

Availability of data and materials: The datasets used and/or analyzed during the current study are available from the corresponding author on reasonable request.

\section{References}

Aghion, P., Howitt, P., Howitt, P. W., Brant-Collett, M., \& García-Peñalosa, C. (1998). Endogenous growth theory. MIT press.

Apergis, N., \& Ozturk, I. (2015). Testing environmental Kuznets curve hypothesis in Asian countries. Ecological indicators, 52, 16-22.

Balcilar, M., Ozdemir, Z. A., Ozdemir, H., \& Shahbaz, M. (2018). The renewable energy consumption and growth in the G-7 countries: Evidence from historical decomposition method. Renewable Energy, 126, 594-604.

Benos, N., \& Zotou, S. (2014). Education and economic growth: A meta-regression analysis. World Development, 64, 669-689.

Bildirici, M. E., \& Gökmenoğlu, S. M. (2017). Environmental pollution, hydropower energy consumption and economic growth: Evidence from G7 countries. Renewable and Sustainable Energy Reviews, 75, 68-85.

Bloch, H., Rafiq, S., \& Salim, R. (2015). Economic growth with coal, oil and renewable energy consumption in China: Prospects for fuel substitution. Economic Modelling, 44, 104-115.

Broadstock, D. C., Fan, Y., Ji, Q., \& Zhang, D. (2016). Shocks and stocks: a bottom-up assessment of the relationship between oil prices, gasoline prices and the returns of Chinese firms. The Energy Journal, 37(China Special Issue).

Broadstock, D. C., Li, J., \& Zhang, D. (2016). Efficiency snakes and energy ladders: A (meta-) frontier demand analysis of electricity consumption efficiency in Chinese households. Energy Policy, 91, 383-396.

Brunel, C., \& Levinson, A. (2016). Measuring the Stringency of Environmental Regulations. Review of Environmental Economics and Policy, 10(1), 47-67.

Démurger, S., \& Fournier, M. (2011). Poverty and firewood consumption: A case study of rural households in northern China. China economic review, 22(4), 512-523.

Galeotti, M., Salini, S., \& Verdolini, E. (2020). Measuring environmental policy stringency: Approaches, validity, and impact on environmental innovation and energy efficiency. Energy Policy, 136, 111052.

Herman, K. S., \& Xiang, J. (2019). Induced innovation in clean energy technologies from foreign environmental policy stringency?. Technological Forecasting and Social Change, 147, 198-207.

Khanna, N. Z., Guo, J., \& Zheng, X. (2016). Effects of demand side management on Chinese household electricity consumption: Empirical findings from Chinese household survey. Energy Policy, 95, 113-125.

Li, B., Chen, Y., Chen, Z., Xiong, H., \& Lian, L. (2016). Why does precipitation in northwest China show a significant increasing trend from 1960 to 2010?. Atmospheric Research, 167, 275-284.

Liu, Z., Liu, Y., He, B. J., Xu, W., Jin, G., \& Zhang, X. (2019). Application and suitability analysis of the key technologies in nearly zero energy buildings in China. Renewable and Sustainable Energy Reviews, 101, 329-345. 
Lucas Jr, R. E. (1988). On the mechanics of economic development. Journal of monetary economics, 22(1), 3-42. Odgaard, O., \& Delman, J. (2014). China' s energy security and its challenges towards 2035. Energy Policy, 71, 107-117.

Ozcan, B., \& Ozturk, I. (2019). Renewable energy consumption-economic growth nexus in emerging countries: A bootstrap panel causality test. Renewable and Sustainable Energy Reviews, 104, 30-37.

Ozturk, I. (2010). A literature survey on energy-growth nexus. Energy policy, 38(1), 340-349.

Pachauri, S., \& Jiang, L. (2008). The household energy transition in India and China. Energy policy, 36(11), 40224035.

Pata, U. K. (2018). Renewable energy consumption, urbanization, financial development, income and CO2 emissions in Turkey: testing EKC hypothesis with structural breaks. Journal of Cleaner Production, 187, 770-779.

Pesaran, M. H., Shin, Y., \& Smith, R. J. (2001). Bounds testing approaches to the analysis of level relationships. Journal of applied econometrics, 16(3), 289-326.

Ratti, R. A., \& Vespignani, J. L. (2013). Why are crude oil prices high when global activity is weak?. Economics Letters, 121(1), 133-136.

Revesz, R. L., \& Stavins, R. N. (2007). Environmental law. Handbook of law and economics, 1, 499-589.

Romer, P. M. (1990). Endogenous technological change. Journal of political Economy, 98(5, Part 2), S71-S102.

Salim, R., Yao, Y., \& Chen, G. S. (2017). Does human capital matter for energy consumption in China?. Energy Economics, 67, 49-59.

Shin, Y., Yu, B., \& Greenwood-Nimmo, M. (2014). Modelling asymmetric cointegration and dynamic multipliers in a nonlinear ARDL framework. In Festschrift in honor of Peter Schmidt (pp. 281-314). Springer, New York, NY.

Ullah, S., \& Ozturk, I. (2020). Examining the asymmetric effects of stock markets and exchange rate volatility on Pakistan's environmental pollution. Environmental Science and Pollution Research, 27, 31211-31220.

Usman, A., Ullah, S., Ozturk, I., Chishti, M. Z., \& Zafar, S. M. (2020). Analysis of asymmetries in the nexus among clean energy and environmental quality in Pakistan. Environmental Science and Pollution Research, 27(17), 20736-20747.

Wang, Q., Zhao, Z., Zhou, P., \& Zhou, D. (2013). Energy efficiency and production technology heterogeneity in China: a meta-frontier DEA approach. Economic Modelling, 35, 283-289.

Yin, Y., Xiong, X., Ullah, S., \& Sohail, S. (2021). Examining the asymmetric socioeconomic determinants of CO2 emissions in China: challenges and policy implications. Environmental Science and Pollution Research, 111.

Yuan, J. H., Kang, J. G., Zhao, C. H., \& Hu, Z. G. (2008). Energy consumption and economic growth: evidence from China at both aggregated and disaggregated levels. Energy Economics, 30(6), 3077-3094.

Zhao, P., Lu, Z., Fang, J., Paramati, S. R., \& Jiang, K. (2020). Determinants of renewable and non-renewable energy demand in China. Structural Change and Economic Dynamics, 54, 202-209. 